\title{
The Impact of Foreign Direct Investment, Labour Force, and External Debt on Economic Growth in Indonesia and Malaysia
}

\author{
Malik Cahyadin \\ Universitas Sebelas Maret \\ Tamat Sarmidi \\ Universiti Kebangsaan Malaysia
}

(Kesan Pelaburan Langsung Asing, Tenaga Kerja dan Hutang Luar Negara ke atas Pertumbuhan Ekonomi di Indonesia dan Malaysia)

ABSTRACT

The study aims to estimate the impact of Foreign Direct Investment (FDI), labour, and external debt on economic growth in Indonesia and Malaysia over the period 1980-2016. The findings are expected to serve as a reference for macroeconomic policies in Indonesia and Malaysia. Employing an Autoregressive Distributed Lag Model (ARDL) and Error Correction Model (ECM), we find that FDI, labour force and external debt have a significant impact on the economic growth in the long-and short-run in both countries. Statistically, the estimated models are stable. Therefore, it is recommended that the authorities in Indonesia and Malaysia should concentrate on attracting more quality FDI inflows and properly manage external debts as well as high-skilled labour force, which are vital to economic growth.

Keywords: economic growth; FDI; labour force; external debt; $A R D L-E C M$

\section{ABSTRAK}

Kajian ini bertujuan untuk menganggarkan kesan pelaburan langsung asing (FDI), tenaga kerja, dan hutang luar negera terhadap pertumbuhan ekonomi di Indonesia dan Malaysia dalam tempoh 1980-2016. Hasil kajian dijangka mampu untuk dijadikan rujukan oleh penggubal dasar makroekonomi di Indonesia dan Malaysia. Menggunakan model autoregresif terdistribusi lat (ARDL) dan model pembetulan ralat (ECM), kami mendapati bahawa FDI, tenaga buruh dan hutang luar negara mempunyai impak yang besar terhadap pertumbuhan ekonomi di kedua-dua negara dalam jangka panjang dan pendek. Secara statistik, model yang dianggarkan adalah stabil. Oleh itu, adalah disyorkan agar pihak pembuat dasar di Indonesia dan Malaysia menumpukan perhatian kepada dasar dan usaha yang boleh menarik lebih banyak aliran masuk FDI yang berkualiti dan mengurus hutang luar negara dengan baik disamping keperluan tenaga buruh berkemahiran tinggi yang penting untuk pertumbuhan ekonomi.

Kata kunci: pertumbuhan ekonomi; FDI; tenaga kerja; hutang luar negara; ARDL-ECM

\section{INTRODUCTION}

Indonesia has endeavoured to encourage FDI inflows as a trigger for improving domestic economy since 1967. This was marked by the enactment of Act No. 1/1967 about foreign investment, and policies on investment liberalisation until now (see policy and publication on Indonesia investment at https://www5.bkpm.go.id). The existence of FDI inflows is also important for the Malaysian economy. Department of Statistics of Malaysia has reported that FDI inflows increase every year, especially from Asia region (see https://www.dosm.gov. my). Hence, the impact of FDI on economic growth in both countries can be further estimated by scrutinizing the matter through a number of questions raised in this study. First, does FDI impact on economic growth both in the short- and the long-run? So far, some empirical researches have used FDI as an independent variable in endogenous growth model.

As we know, Indonesia is the country with the largest population in the ASEAN region. According to the World Bank data, the total number of Indonesia labour force in 1980 was 52 million, which increased to 127 million in 2016 (grew by 144\%). Meanwhile, the total labour force in Malaysia increased from 5 million in 1980 to 14 million in 2016 (grew by 180\%). This situation can be addressed to the domestic economy in both countries in order to calculate the impact of labour force. Thus, the second research question is: Does labour force impact on economic growth both in the short- and the long-run?

In 1967 donor countries for Indonesia have formed IGGI (Inter-Governmental Group on Indonesia) as the starting point for Indonesia's active role in foreign debt contracts. The growth of Indonesian external debt is about 
$1,411 \%$ (1980 to 2016). At present the management and supervision of Indonesian foreign debt have been carried out by the Ministry of Finance and Bank Indonesia. Moreover, the Malaysian economy was also obliged to accumulate debt as a result from budget deficit. According to Daud (2016), the Malaysian government debt was financed from domestic borrowing (about 96.2\%) and foreign borrowing (about 3.8\%). Thus, this research aims to calculate the impact of total debt to domestic economy in both countries. Thus, the third research question is: Does external debt impact on economic growth both in the short- and the long-run?

Foreign Direct Investment (FDI) and labour play an important role in driving the domestic economy of a country. In addition, the availability of funds in the form of external debt is also important to stimulate economic growth. Studies on the impacts and contribution of these three variables to economic growth have been done by Paudel and Perera (2009), Aljebrin (2012), Ullah et al. (2014), Nordin et al. (2014), and ILO, OECD and the World Bank Group (2015). However, several empirical studies indicate that FDI and external debt have minimum contribution to the domestic economy (Duasa 2007; Wehinger 2011; Aurangzeb \& Haq 2012; Mohamed et al. 2014).

According to Duasa (2007), there was no causality between Gross Domestic Products (GDP) and FDI, so the government is encouraged to increase FDI inflow and economic stability. Meanwhile, Paudel and Perera (2009) found that in the long-run, foreign debt and labour
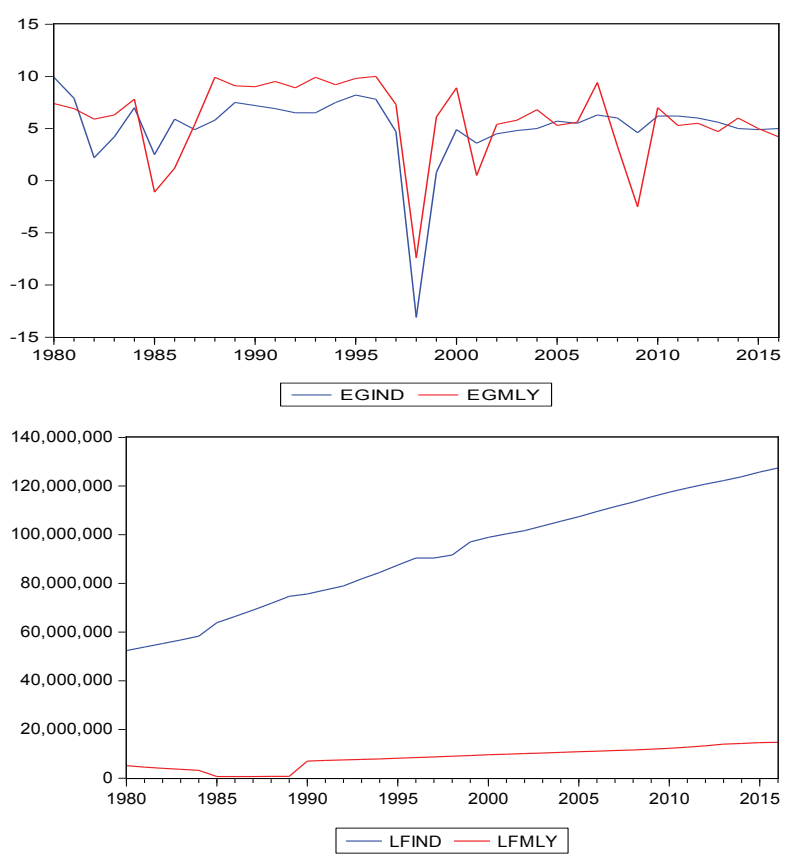

significantly influenced economic growth in Sri Lanka. These two empirical findings show that the long- and the short-run investments do not contribute significantly to the economy. Wehinger (2011) encourages the Organization for Economic Cooperation and Development (OECD) countries to formulate regulations stimulating higher economic investment levels. Moreover, ILO, OECD and the World Bank Group (2015) emphasize the importance of the availability of highly educated and skilled labour. As an important production input, labour force should not be focused only on their quantity but also their quality.

Indonesia is a country in the ASEAN region that is trying to promote its economic growth through the availability of funds from FDI and external debt and seeks to encourage labour absorption. Thus, FDI and external debt are important sources of funding for the domestic economy and the ability of the economy to absorb labour is crucial as well. According to Sailiwa (2013), several important aspects that are driving the Indonesian and Malaysian economies include the benefits of the ASEAN economic community to promote economic growth, shared market potential, investment destination countries, and open service sectors. In addition, the two countries have cooperated both in the economic and non-economic sectors to encourage domestic and regional economy.

Figure 1 illustrates the development of FDI, labour force, external debt, and economic growth in Indonesia and Malaysia within the period of 1980-2016. Economic growth in both countries tended to fluctuate. The economic crisis of $1997 / 1998$ had a significant impact
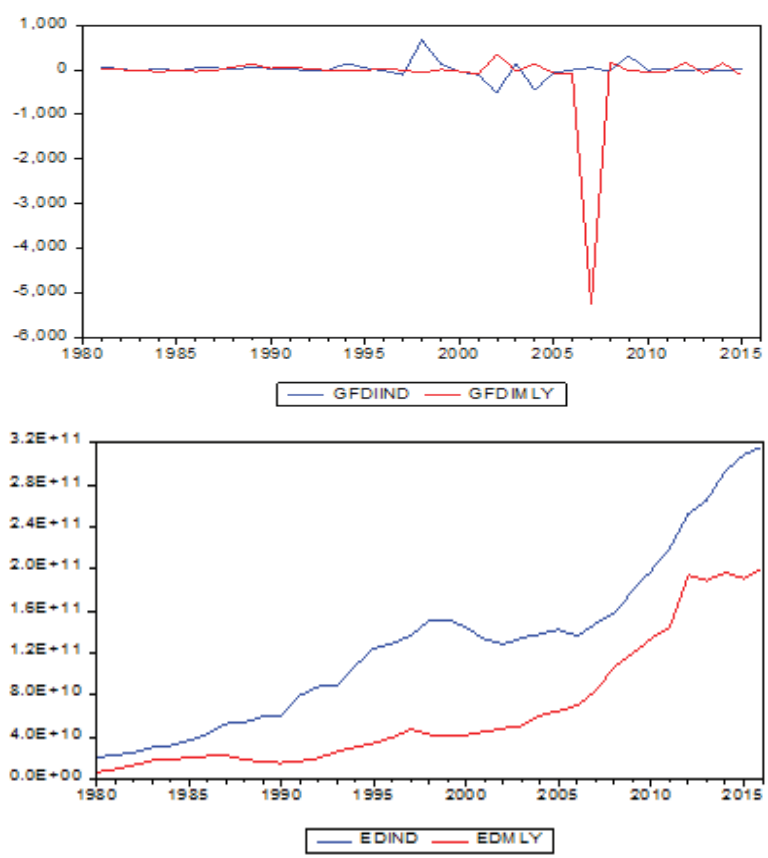

FIGURE 1. The Development of Research Variables, 1980-2016 Source: The World Bank

Note: $\quad$ EGIND = economic growth of Indonesia (\%); EGMLY = economic growth of Malaysia (\%); GFDIIND = growth of FDI in Indonesia (\%); GFDIMLY = growth of FDI in Malaysia (\%); LFIND = total labour force in Indonesia (person); LFMLY = total labour force in Malaysia (person); EDIND = total external debt in Indonesia (USD); and EDMLY = total external debt in Malaysia (USD). 
on the decline of economic growth in both countries. In addition, the subprime mortgage crisis also resulted in Malaysia's economic downturn in 2008 although not as significant as the previous economic crisis. The development of FDI was relatively stable in both Indonesia and Malaysia, but a gap was seen between FDI inflows and outflows. In 2006-2007, Malaysia's FDI growth tended to be lower as a result of greater FDI inflow compared to FDI outflow. This means that, during that period, there was a significant shift between FDI inflows and outflows in Malaysia.

The number of labour force in Indonesia and Malaysia tends to increase, with Indonesia having a bigger increase. This condition is influenced by the efforts of both countries to increase labour absorption. The number of labour force in Indonesia is much larger because of its larger population. External debt in both countries also tends to increase with a relatively similar value. This means that governments and business actors in both countries are relatively related to overseas donors/ institutions. In addition, both countries make external debt an important part of driving the domestic economy. However, both countries need to improve external debt management capabilities and focus the debt on improving the domestic economy.

The important contribution of this research is the impact analysis of long- and short-run relationships between FDI, labour force, and external debt on economic growth. In addition, the relationship can be a reference for the Indonesian and Malaysian governments to increase the attractiveness of FDI inflow, manage external debt, and improve labour force. These three variables will be expected to encourage the economic growth.

This paper is organised into six parts: introduction; literature review; methodology; result and discussion; conclusion, implication, and limitation; and, reference. The data set, and ARDL-ECM model will be discussed in the methodology part. Meanwhile, the result and discussion part will elaborate descriptive statistics, unit root test, bound test, ARDL estimation, ARDL-ECM estimation, and stability test.

\section{LITERATURE REVIEW}

Helbling et al. (2004) explained that the availability of small investment would have an impact on the low capability of economic growth and employment. Buffie et al. (2012) suggested that public investment could be loosened primarily in the long run to boost economic performance. In addition, according to Phetsavong and Ichihashi (2012), FDI policy should be formulated carefully and appropriately to maintain economic growth. These three studies demonstrate the need for sufficient and well-managed investment to promote economic growth. In theory, investment is related to aggregate demand and supply.
Romer (2012) believed that the increase in supply and demand for aggregate output would encourage the availability of capital stock. As such, the economy needs to maintain investment availability as it becomes a funding source to develop industry and grow the economy. This view is supported by Nordin et al. (2014) who confirmed that FDI's important contribution to economic growth is the availability of capital and transfer of technology, and by Suhendra and Anwar (2014) who found that investment has a positive and significant impact on economic growth. These three arguments are the foundations of this research. To clarify the impact of investment on economic growth both in the short- and the long-run, the ARDL method is used. This is done because the period of research data is relatively short.

Poirson (2000) argued that countries capable of reallocating labour from agriculture to industry efficiently tend to generate high economic growth. Such reallocation, which requires increased skill and higher education, increase labour productivity in the industrial sector. ILO, OECD, \& World Bank Group (2015) also reported that highly skilled labour can promote economic growth, which was confirmed by Hsu (2017) who mentioned that labour could push the economy through productivity. The labour variable in this research is in the form of total labour force, not the human capital. Labour force becomes a proxy for workers availability as production input that can increase aggregate output and stimulate economic growth. Thus, the labour force is believed to have a positive and significant impact on economic growth.

Pattillo et al. (2004) found that the relatively high debt has a negative and significant effect on economic growth, but the debt on a small scale shows no such effect. Nersisyan and Wray (2010) argued that large or small impact of government debt on macro economy does not necessarily refer to a certain level/percentage but rather than to the consequences of state budget policy and economic performance target. Meanwhile, Wijeweera et al. (2005) stated that external debt affects the economy in the short-run but it is not significant in the long-run. This argument is the reference of this study to prove the difference between the impacts of external debts in the short-run and those in the long-run on economic growth in both Indonesia and Malaysia.

Emeka and Mojekwu (2011) noted that external debt has a significant impact on GDP but foreign capital inflow has no effect. In addition, Umaru et al. (2013) pointed out that external debt has a negative effect on economic growth so the government needs to focus on increasing investment, rather than external debt. However, Mengus (2014) maintained that the Ricardian-based economy could utilize the availability of debt (external-domestic) appropriately to economic development. These three arguments have shown that FDI and external debt remain important in promoting economic growth in both Indonesia and Malaysia. 
There are several theories of economic growth that can be used as a research reference, namely, the structuralist growth model, the classical theory of growth and distribution, evolutionary growth theory, the post-Keynesian theories of growth and distribution, the Harrodian and Kaleckian models of accumulation and income distribution, Kaldor and the Kaldorians, and the paths of transformational growth (Setterfield 2010). The structuralist growth model emphasizes that the economic output is formed due to economic structure factors, where investment does not necessarily have a direct effect on the economy (Gibson 2010 in Setterfield 2010). In this condition, price and income can be well distributed. Foley and Michl (2010) in Setterfield (2010) suggested that the classical theory of growth and distribution identifies several factors that shape economic growth, namely: investment, employment, population, and savings. In addition, the resource distribution factor in the production process can improve output added-value. Evolutionary growth theory describes that knowledge, population, and investment play an important role in the evolution of economic growth (Metcalfe \& Foster 2010 in Setterfield 2010). According to Kurz and Salvadori (2010) in Setterfield (2010), the post-Keynesian theories of growth and distribution emphasize the linkage between wages, profits, technology, and economic growth.

In Indonesia, empirical research on the contribution of FDI, labour force, and external debt to economic growth has been done by Hafild et al. (2000), Rininta (2013), Tarmidi et al. (2014), Allen (2016), Feriyanto and Sriyana (2016), Sjöholm (2016), Giap and Amri (2016), Gopalan et al. (2016), Kentjana (2017), and Mahadika et al. (2017). In general, FDI has a significant impact on economic growth. This condition is relevant to the governments' efforts to increase investment sources to stimulate economic development. The availability of labour also contributes to the economic growth. However, the contribution of labour has not been maximized to achieve higher levels of economic growth. On the other hand, external debt tends to be a burden on the state budget and has less significant impact on economic growth.

In Malaysia, empirical research on the impact of FDI, labour force, and external debt on economic growth has been carried out by among others: Mun et al. (2008); Bakar and Hassan (2008); Aw and Tang (2009); Hooi and Wah (2010); Loganathan et al. (2010); Yusof (2010); Hassan and Masron (2011); Wye and Ismail (2012); Haseeb et al. (2014); Sieng and Yussof (2014); Solomon et al. (2015); Rafik (2015); and, Munir et al. (2016). In general, FDI inflows have a significant impact on Malaysia's domestic economy, as it can absorb labour. Therefore, the government is encouraged to utilize FDI optimally. Labour plays an important role in Malaysia's economic growth, but workers are treated differently by gender. It has also been shown that external debt holds a significant impact on the Malaysian economy.
As Malaysia's external debt tends to increase, the government is expected to manage it carefully so as not to become the burden of domestic economy.

This study will examine the significant impact of FDI, labour force, and external debt on economic growth of Indonesia and Malaysia in both the short- and the long-run. The three variables, which are all independent, were chosen as a comparison with previous empirical researches that tend to focus on one or two independent variables in the estimation model. The result of the study is expected to be a significant contribution in the form of empirical contribution. In addition, this research uses macroeconomic variables. Several previous empirical researches tend to focus on combining macroeconomic and microeconomic (industry level) variables. Thus, previous empirical studies do not link these three independent variables on economic growth in one model of estimation directly.

As FDI has a significantly positive impact on economic growth in Indonesia and Malaysia, the two countries need to create a favourable investment climate and make deals for special projects, such as infrastructure, energy, electricity, and manufacture accordingly. Meanwhile, the external debt can be used to stimulate skilled labour, technology adoption for SMEs, innovation and technology project for education, and subsidy for manufacture. Furthermore, the two countries should design risk management of external debt in order to control the risk of volatility value of external debt on domestic economic growth. Moreover, the external debt in growth model can extend the traditional growth model. Given the traditional growth model which is just constituted by capital and labour, then some researchers conducted empirical studies to investigate the impact and optimal level of debt on the domestic economy.

\section{METHODOLOGY}

\section{DATA SET}

This research uses annual secondary data from 1980-2016 published by the World Bank (www.worldbank.org). In addition, it also focuses on two countries, i.e., Indonesia and Malaysia as the research objects. The initial period of research refers to empirical studies conducted by Hakim and Giovani (2012) and Drabble (2000). Hakim and Giovani (2012) explained that Indonesia's economic growth has been growing rapidly since 1980 as a result of economic stabilization, availability of investment, and foreign debt cooperation. Meanwhile, Drabble (2000) points out that in the 1980s Malaysia's manufacturing developments improved in favour of improving domestic economic conditions. Furthermore, the end period of this research is 2016, which is based on the availability of latest data published by the World Bank. 
The research variables include Foreign Direct Investment (FDI), labour force, external debt, and economic growth. The FDI uses net FDI inflows in US\$. Labour force data is the number of worker in person. External debt data is total private and public debt in US\$. All data will be converted into logarithms for the ARDLECM estimation model. Meanwhile, economic growth data represents annual GDP growth in \%.

Research data in ARDL-ECM estimation use several symbols. Symbol of Indonesia and Malaysia are IND and MLY respectively. In addition, the symbol of economic growth uses EG. Meanwhile, the symbol of FDI, labour force and external debt are FDI, LF, and ED respectively. Thereby, the symbols of ARDL-ECM variables in Indonesia are EGIND, logFDIIND, logLFIND, dan logEDIND. Furthermore, the symbols of ARDL-ECM variables in Malaysia are EGMLY, logFDIMLY, logLFMLY, and $\log$ EDMLY respectively.

\section{METHOD}

Some empirical studies are employed to examine the impact of FDI, labour force, and external debt on economic growth in Indonesia dan Malaysia in the short- and the long-run. Those empirical researches are conducted by Mun et al. (2008), Hooi and Wah (2010), Tarmidi et al. (2014), Sieng and Yussof (2014), and Mahadika et al. (2017). Generally, the output is determined by capital and labour (see Cobb-Douglas Production Function). In this research, however, the output is defined by GDP growth (economic growth) while capital is defined by Foreign Direct Investment (FDI) inflows. The investment of this research is calculated using q-Theory (see Wickens 2008). In addition, the labour uses labour force data. The relationsip between labour and economic growth refers to Endogenous Growth Model (see Romer 2012). Furthermore, external debt, which is used as independent variable in this study, becomes source of growing domestic economy. The impact of debt on economic growth uses Endogenous Growth Model (see Greiner and Fincke 2015, 81-101). The total external debt from foreign investors or countries was the one obtained by public and private sectors.

The ARDL model was used to investigate the impact of FDI, labour force, and external debt on economic growth in Indonesia and Malaysia in the long-run. The basic model of ARDL in this research refers to the one constructed by Pesaran and Shin (1995), which is formulated as follows (see Equation 1):

$$
\begin{aligned}
\Delta E G_{t}= & \alpha+\sum_{i=1}^{n} b_{i} \Delta E G_{t-i}+\sum_{i=1}^{n} c_{i} \Delta F D I_{t-i}+ \\
& \sum_{i=1}^{n} d_{i} \Delta L F_{t-i}+\sum_{i=1}^{n} e_{i} \Delta E D_{t-i}+\beta_{1} E G_{t-1}+ \\
& \beta_{2} F D I_{t-1}+\beta_{3} L F_{t-1}+\beta_{4} E D_{t-1}+\varepsilon_{t}
\end{aligned}
$$

$\triangle \mathrm{EG}$ is change of economic growth $(\%) . \Delta \mathrm{FDI}$ is change of foreign direct investment (US $\$$ ). $\Delta$ LF is change of labour force (person). $\Delta \mathrm{ED}$ is change of external debt (US\$). $\alpha$ is constant or intercept of ARDL estimation.
Meanwhile, b; c; d; e; and $\beta$ are parameters of independent variables. Those parameters will explain the impact of FDI, labour force, and external debt on economic growth both in the long- and the short-run.

Equation 1 was converted to logarithms. Therefore, Equation 2 could be written as follows:

$$
\begin{aligned}
& \Delta E G_{t}=\alpha+\sum_{i=1}^{n} b_{i} \Delta E G_{t-i}+\sum_{i=1}^{n} c_{i} \Delta \log F D I_{t-i}+ \\
& \sum_{i=1}^{n} d_{i} \Delta \log L F_{t-i}+\sum_{i=1}^{n} e_{i} \Delta \log E D_{t-i}+ \\
& \beta_{1} E G_{t-1}+\beta_{2} \log F D I_{t-1}+\beta_{3} \log L F_{t-1}+ \\
& \beta_{4} \log E D_{t-1}+\varepsilon_{t}
\end{aligned}
$$

Based on Equation 2, the ARDL model to be employed is as follows (Equation 3):

$$
\begin{aligned}
E G_{t}= & \alpha+\sum_{i=1}^{n} b_{i} E G_{t-i}+\sum_{i=1}^{n} c_{i} \log F D I_{t-i}+ \\
& \sum_{i=1}^{n} d_{i} \log L F_{t-i}+\sum_{i=1}^{n} e_{i} \log E D_{t-i}+\varepsilon_{t}
\end{aligned}
$$

Equation 3 explains the long-run impact of FDI, labour force, and external debt on economic growth.

In order to examine the short-run impact of FDI, labour force, and external debt, the ECM model is employed as follows (Equation 4):

$$
\begin{aligned}
\Delta E G_{t}= & \alpha+\sum_{i=1}^{n} \gamma_{1 i} \Delta E G_{t-i}+\sum_{i=1}^{n} \gamma_{2 i} \Delta \log F D I_{t-i}+ \\
& \sum_{i=1}^{n} \gamma_{3 i} \Delta \log F_{t-i}+\sum_{i=1}^{n} \gamma_{4 i} \log E D_{t-i}+ \\
& \gamma_{5 i} E C T_{t-1}+e_{t}
\end{aligned}
$$

ECT is an error correction term that reflects ECM Model in the short-run. Meanwhile, $\gamma$ is parameter of ECM estimation.

The unit root test of all research variables uses Augmented Dickey-Fuller (ADF) and Phillips-Perron (PP) test. The basic procedure of ADF and PP test refers to Maddala and Kim (2004). In addition, the unit root test will use level and first difference (intercept, and intercept and trend). Furthermore, the final step of research analysis is stability test. It uses recursive estimation with CUSUM and CUSUM Sum of Square (CUSUMSQ) for getting a constancy of parameter in the model (Pesaran \& Pesaran 1997 in Alimi 2014).

\section{RESULT AND DISCUSSION}

\section{DESCRIPTIVE STATISTICS}

Table 1 (Indonesia) and Table 2 (Malaysia) provide information on the descriptive statistics of research variables. Table 1 indicates that Economic Growth (EGIND) and log FDI (logFDIIND) tend to be abnormally distributed. This can be observed from the Skewness value that tends to be negative and kurtosis value that is very high. Both produce a relatively high JarqueBera value, which means that the probability value is significant. Meanwhile, the Skewness value of the $\log$ labour force (logLFIND) and the external debt log ( $\log$ EDIND) tends to be close to 0 while the Kurtosis value of these variables is below 3, resulting in a Jarque-Bera value of nearly 3 . This indicates that the 
TABLE 1. Descriptive Statistics of Variables in Indonesia

\begin{tabular}{lcccc}
\hline Variables & EGIND & LOGFDIIND & LOGLFIND & LOGEDIND \\
\hline Mean & 5.1514 & 9.7576 & 7.9489 & 11.0075 \\
Median & 5.7000 & 10.1614 & 7.9621 & 11.1229 \\
Maximum & 9.9000 & 10.3128 & 8.1052 & 11.5003 \\
Minimum & -13.1000 & 0.0000 & 7.7195 & 10.3209 \\
Std. Dev. & 3.5384 & 1.6800 & 0.1172 & 0.3317 \\
Skewness & -3.8011 & -5.5098 & -0.4864 & -0.5617 \\
Kurtosis & 20.4464 & 32.4947 & 2.0639 & 2.3495 \\
Jarque-Bera & 558.3487 & 1528.3600 & 2.8096 & 2.5979 \\
Probability & 0.0000 & 0.0000 & 0.2454 & 0.2728 \\
Observations & 37 & 37 & 37 & 37 \\
\hline
\end{tabular}

Source: Secondary data (processed)

Note: $\quad$ EGIND = economic growth of Indonesia (\%), LOGFDIIND = logarithm of Indonesia FDI, LOGEDIND $=$ logarithm of Indonesia external debt

two variables tend to be normally distributed and their probability value is not significant.

As shown in Table 2, economic growth of Malaysia (EGMLY) and log labour force (logLFMLY) appear to be abnormally distributed. This can be observed from the skewness value that tends to be closer to 1 and from the kurtosis value that is higher than 4. Both produce a relatively high Jarque-Bera value and a significant probability value. Meanwhile, the skewness value of the $\log$ FDI ( $\log$ FDIMLY) and the log external debt (logEDMLY) tend to be close to 0 while the kurtosis value of these variables is below 3 , resulting in a relatively low JarqueBera value and insignificant probability value. All these values indicate the two variables that are likely to be normally distributed.

\section{UNIT ROOT TESTS}

Unit Root Test is applied to time series data to get data stationarity (Maddala and Kim 2004). The data may indicate that they are normally distributed. This test is performed on FDI, labour force, external debt, and economic growth data in Indonesia and Malaysia. The tests used were Augmented Dickey-Fuller (ADF) test and Phillips-Perron (PP), which were determined at level and at first difference. The tests also employed intercept and intercept and trend.

Table 3 presents the results of Unit Root Test in which economic growth of Indonesia (EGIND) and log labour force (logLFIND) are stationary at level in the ADF (intercept, intercept and trend) and PP (intercept, and intercept and trend). Meanwhile, FDI log variables (logFDIIND) and the external debt $\log (\log$ EDIND) are stationary at first difference in ADF (intercept) and PP (intercept, and intercept and trend).

As shown in Table 4, the economic growth of Malaysia (EGMLY) is stationary at level in the ADF (intercept, intercept and trend) and PP (intercept, and intercept and trend). Meanwhile, $\log$ FDI (logFDIMLY), $\log$ labour force (logLFMLY) and the external debt log (logEDMLY) are stationary at first difference in ADF (intercept) and PP (intercept, and intercept and trend).

TABLE 2. Descriptive Statistics of Variables in Malaysia

\begin{tabular}{lcccc}
\hline \multicolumn{1}{c}{ Variables } & EGMLY & LOGFDIMLY & LOGLFMLY & LOGEDMLY \\
\hline Mean & 5.8730 & 9.8636 & 6.7976 & 10.6340 \\
Median & 6.1000 & 9.8699 & 6.9538 & 10.6230 \\
Maximum & 10.0000 & 10.2175 & 7.1673 & 11.3018 \\
Minimum & -7.4000 & 9.5207 & 5.8056 & 9.8202 \\
Std. Dev. & 3.7641 & 0.1871 & 0.4195 & 0.4080 \\
Skewness & -1.5944 & -0.0433 & -1.5667 & 0.1526 \\
Kurtosis & 5.9137 & 2.6718 & 4.1164 & 2.0905 \\
Jarque-Bera & 28.7648 & 0.1729 & 17.0577 & 1.4188 \\
Probability & 0.0000 & 0.9172 & 0.0002 & 0.4919 \\
Observations & 37 & 37 & 37 & 37 \\
\hline
\end{tabular}

Source: Secondary data (processed)

Note: EGMLY = economic growth of Malaysia (\%), LOGFDIMLY = logarithm of Malaysia FDI, LOGEDMLY $=$ logarithm of Malaysia external debt 
TABLE 3. Unit Root Test Results of Variables in Indonesia

\begin{tabular}{lcccccccc}
\hline & \multicolumn{3}{c}{ Augmented Dickey-Fuller (ADF) test } & \multicolumn{3}{c}{ Phillips-Perron (PP) test } \\
\cline { 2 - 9 } Variables & \multicolumn{2}{c}{ Level } & \multicolumn{2}{c}{ First Difference } & \multicolumn{2}{c}{ Level } & \multicolumn{2}{c}{ First Difference } \\
\cline { 2 - 9 } & \multicolumn{3}{c}{$\begin{array}{c}\text { Intercept } \\
\text { and Trend }\end{array}$} & Intercept & $\begin{array}{c}\text { Intercept } \\
\text { and Trend }\end{array}$ & $\begin{array}{c}\text { Intercept } \\
\text { Intercept }\end{array}$ & $\begin{array}{c}\text { Intercept } \\
\text { and Trend }\end{array}$ & $\begin{array}{c}\text { Intercept } \\
\text { Intercept } \\
\text { and Trend }\end{array}$ \\
\hline EGIND & $-4.53115^{\mathrm{a}}$ & $-4.446526^{\mathrm{b}}$ & - & - & $-4.543694^{\mathrm{a}}$ & $-4.460387^{\mathrm{b}}$ & - & - \\
LOGFDIIND & -0.587891 & -2.542309 & $-2.796641^{\mathrm{c}}$ & -3.034973 & 0.492332 & -1.043521 & $-11.45623^{\mathrm{a}}$ & $-13.0893^{\mathrm{a}}$ \\
LOGLFIND & $-5.742505^{\mathrm{a}}$ & $-4.506987^{\mathrm{b}}$ & - & - & $-7.536914^{\mathrm{a}}$ & -0.669384 & - & - \\
LOGEDIND & -2.23708 & -1.718838 & $-4.466286^{\mathrm{a}}$ & $-4.762234^{\mathrm{b}}$ & -1.980998 & -1.779084 & $-4.535197^{\mathrm{a}}$ & $-4.779564^{\mathrm{b}}$ \\
\hline
\end{tabular}

Source: Secondary Data (processed)

Note: 1. MacKinnon (1996) $\mathrm{a}=1 \% ; \mathrm{b}=5 \%$; and $\mathrm{c}=10 \%$

2. Max. lag is 9 based on Schwarz information criterion

TABLE 4. Unit Root Test Results of Variables in Malaysia

\begin{tabular}{|c|c|c|c|c|c|c|c|c|}
\hline \multirow{3}{*}{ Variables } & \multicolumn{4}{|c|}{ Augmented Dickey-Fuller test } & \multicolumn{4}{|c|}{ Phillips-Perron test } \\
\hline & \multicolumn{2}{|c|}{ Level } & \multicolumn{2}{|c|}{ First Difference } & \multicolumn{2}{|c|}{ Level } & \multicolumn{2}{|c|}{ First Difference } \\
\hline & Intercept & $\begin{array}{l}\text { Intercept } \\
\text { and Trend }\end{array}$ & Intercept & $\begin{array}{l}\text { Intercept } \\
\text { and Trend }\end{array}$ & Intercept & $\begin{array}{l}\text { Intercept } \\
\text { and Trend }\end{array}$ & Intercept & $\begin{array}{l}\text { Intercept } \\
\text { and Trend }\end{array}$ \\
\hline EGMLY & $-4.812069^{\mathrm{a}}$ & $-4.872854^{\mathrm{b}}$ & - & - & $-4.827285^{\mathrm{a}}$ & $-4.872854^{\mathrm{a}}$ & - & - \\
\hline LOGFDIMLY & -1.646518 & -1.936499 & $-6.078486^{\mathrm{a}}$ & $-5.930288^{a}$ & -1.596293 & -1.936499 & $-6.08372^{\mathrm{a}}$ & $-5.938728^{\mathrm{a}}$ \\
\hline LOGLFMLY & $-16.34209^{a}$ & -2.392052 & $-5.525874^{\mathrm{a}}$ & $-5.456593^{\mathrm{a}}$ & -1.454045 & -2.544352 & $-5.525091^{\mathrm{a}}$ & $-5.45602^{\mathrm{a}}$ \\
\hline LOGEDMLY & -1.280515 & $-3.479225^{\mathrm{c}}$ & $-3.556843^{\mathrm{b}}$ & $-3.464627^{\mathrm{c}}$ & -1.19079 & -2.750203 & $-3.429959^{\mathrm{b}}$ & $-3.246765^{\mathrm{c}}$ \\
\hline
\end{tabular}

Source: Secondary Data (processed)

Note: 1. MacKinnon (1996) $\mathrm{a}=1 \% ; \mathrm{b}=5 \%$; and $\mathrm{c}=10 \%$

2. Max. lag is 9 based on Schwarz information criterion

\section{ARDL BOUND TEST}

All the research variables employed in ARDL-ECM estimation both in Indonesia and Malaysia have different root units. There are some variables that have stationary at the level and others have stationary at first difference. The further testing step is cointegration using ARDL Bound Test. The result of cointegration of ARDL Bound Test can be seen at Table 5. The basic test of bound test refers to the one conducted by Pesaran et al. (2001).

Table 5 shows the value of F-statistics of ARDL Bound Test in Indonesia and Malaysia. The value F-statictics is higher than critical value bounds. This indicates that all

TABLE 5. ARDL Bound Test of Indonesia and Malaysia

\begin{tabular}{|c|c|c|c|}
\hline \multicolumn{2}{|c|}{ Indonesia } & \multicolumn{2}{|c|}{ Malaysia } \\
\hline F-Statistic & K & F-Statistic & $\mathrm{K}$ \\
\hline 32.28238 & 3 & 8.767975 & 3 \\
\hline \multicolumn{4}{|c|}{ Critical Value Bounds } \\
\hline Signi & & $\mathrm{I}(0)$ Bound & I(1) Bound \\
\hline & $10 \%$ & 2.72 & 3.77 \\
\hline & $5 \%$ & 3.23 & 4.35 \\
\hline & $2.50 \%$ & 3.69 & 4.89 \\
\hline & $1 \%$ & 4.29 & 5.61 \\
\hline
\end{tabular}

Source: Secondary Data (Processed) research variables have been integrated in the long-run. In addition, the results of the Bound Test can support the ARDL estimation result that FDI, labour force, and external debt have a significant impact on economic growth both in Indonesia and Malaysia.

\section{ARDL ESTIMATION RESULTS}

The ARDL estimation in this research focuses on the impact of FDI, labour force, and external debt on economic growth in Indonesia and Malaysia. Table 6 shows the results of ARDL estimation in Indonesia. It can be seen in Table 6 that the Indonesian ARDL model is $\operatorname{ARDL}(3,6,6,6)$. Economic growth $(-1)$ and economic growth $(-3)$ have a negative and significant impact on the economic growth of Indonesia while economic growth $(-2)$ has a positive and significant impact. This indicates that the lagged economic growth can be a determinant of the economic growth.

FDI and FDI (-1) have a negative impact on Indonesia's economic growth. This indicates that FDI has an influence on economic growth. Meanwhile, FDI (-2) and FDI (-6) have a positive and significant impact on economic growth. Thus, the FDI inflow in the domestic economy needs to be managed properly to ensure the utilization of FDI that can promote economic growth. 
TABLE 6. ARDL Estimation of Indonesia

\begin{tabular}{lccc}
\hline Variables & Coefficient & Std. Error & t-Statistic \\
\hline C & 458.2548 & 103.5903 & $4.423725^{* *}$ \\
EGIND(-1) & -0.459002 & 0.117876 & $-3.893931^{* * *}$ \\
EGIND(-2) & 0.937913 & 0.107188 & $8.750134^{*}$ \\
EGIND(-3) & -0.761487 & 0.095227 & $-7.996552^{*}$ \\
LOGFDIIND & -11.49302 & 1.80024 & $-6.38416^{*}$ \\
LOGFDIIND(-1) & -8.538739 & 1.9002 & $-4.493601^{* *}$ \\
LOGFDIIND(-2) & 9.12498 & 2.550697 & $3.577446^{* * *}$ \\
LOGFDIIND(-3) & -2.972268 & 2.957718 & -1.004919 \\
LOGFDIIND(-4) & 1.435768 & 2.919044 & 0.491862 \\
LOGFDIIND(-5) & -4.062556 & 2.696932 & -1.506362 \\
LOGFDIIND(-6) & 4.088329 & 0.324419 & $12.60202^{*}$ \\
LOGLFIND & -303.7155 & 95.33903 & $-3.185637^{* *}$ \\
LOGLFIND(-1) & 1268.406 & 153.9289 & $8.240208^{*}$ \\
LOGLFIND(-2) & -1478.246 & 116.3267 & $-12.70771^{*}$ \\
LOGLFIND(-3) & 77.26203 & 57.26496 & 1.349203 \\
LOGLFIND(-4) & 338.0907 & 54.38343 & $6.216796^{*}$ \\
LOGLFIND(-5) & -121.5177 & 47.95321 & $-2.534089^{* *}$ \\
LOGLFIND(-6) & 233.7127 & 43.02793 & $5.431652^{*}$ \\
LOGEDIND & 3.056491 & 10.25702 & 0.29799 \\
LOGEDIND(-1) & -47.90605 & 10.46601 & $-4.577301^{* *}$ \\
LOGEDIND(-2) & -6.301948 & 9.416678 & -0.669233 \\
LOGEDIND(-3) & -35.28133 & 11.02938 & $-3.198849^{* *}$ \\
LOGEDIND(-4) & 71.90261 & 11.22309 & $6.406666 *$ \\
LOGEDIND(-5) & -5.694189 & 10.30928 & -0.552336 \\
LOGEDIND(-6) & -18.55391 & 9.233149 & $-2.009489^{* * *}$ \\
R-squared & 0.98681 & & \\
Adjusted R-squared & 0.93405 & & \\
F-statistic & 18.70364 & & \\
Prob(F-statistic) & 0.000749 & & \\
\hline Soure: Seconty Dat & (processed) & & \\
\hline
\end{tabular}

Source: Secondary Data (processed)

Note: a. Dependent variable $=$ EGIND

b. * $\alpha=1 \%$;* $\alpha=5 \%$; ** $\alpha=10 \%$

Labour force, labour force (-2), and labour force $(-5)$ also have a negative and significant impact on Indonesia's economic growth. This confirms that the variables cannot support economic growth. Meanwhile, labour force $(-1)$, labour force (-4), and labour force
(-6) have a positive and significant impact on economic growth. This indicates that the increase in the labour force of previous periode will increase economic growth. Thus, the Indonesian government should stimulate the improvement of labour force in terms of skill and productivity to support economic growth.

External debt and external debt $(-4)$ have a positive and significant impact on Indonesia's economic growth. This proves that external debt can promote economic growth. Meanwhile, external debt lag 1, lag 2, lag 3 , lag 5 and lag 6 have a negative and significant impact on economic growth. External debt by both the government and the private sector need to be properly managed to be used as a driving force of economic growth rather than the burden of the state or company budget.

The adjusted R-squared value of the Indonesian ARDL estimation is 0.93405 . This indicates that the variation of dependent variables is explained by the independent variable variation by $93.405 \%$. In addition, this value is also a goodness of fit indicator of the relatively good estimation of Indonesia's ARDL. Furthermore, the Indonesian ARDL estimation of F-statistic value is significant, which indicates that all the independent variables simultaneously have a significant effect on the dependent variables.

The impacts of FDI and external debt on Indonesia's economic growth were significant in the long-run (Table 7). Meanwhile, the labour force does not affect economic growth significantly, which means that the Indonesia economy still needs capital from foreign countries.

Table 8 illustrates the results of Malaysia's ARDL estimation of the impact of FDI, labour force, and external debt on economic growth. The Malaysian ARDL estimation model is ARDL $(4,4,3,3)$. It can be seen that economic growth $(-2)$ has a negative and significant impact on Malaysia's economic growth, indicating the need for Malaysian government to investigate the economic growth achieved from the previous period in more depth.

FDI has a negative and significant effect on Malaysia's economic growth. This indicates that FDI inflow tends to inhibit domestic economic growth. Thus, the Malaysian government should stimulate FDI

TABLE 7. Long-Run Coefficient of Indonesia's ARDL Estimation

\begin{tabular}{lcccc}
\hline Variable & Coefficient & Std. Error & t-Statistic & Probability \\
\hline LOGFDIIND & -5.340858 & 1.087873 & $-4.90945^{*}$ & 0.0027 \\
LOGLFIND & -5.157389 & 8.151397 & -0.6327 & 0.5503 \\
LOGEDIND & -52.018307 & 4.505976 & $-11.544292^{*}$ & 0.0000 \\
C & -24.163252 & 52.865937 & -0.457067 & 0.6637 \\
\hline
\end{tabular}

Source: Secondary Data (Processed)

Note: a. Dependent variable is EGIND

b. $* \alpha=1 \% ; * * \alpha=5 \% ; * * * \alpha=10 \%$ 
TABLE 8. ARDL Estimation of Malaysia

\begin{tabular}{lccc}
\hline Variables & Coefficient & Std. Error & t-Statistic \\
\hline C & 184.3048 & 54.38218 & $3.389067^{* *}$ \\
EGMLY(-1) & 0.073254 & 0.154292 & 0.474778 \\
EGMLY(-2) & -0.840633 & 0.20181 & $-4.165465^{*}$ \\
EGMLY(-3) & -0.215221 & 0.163193 & -1.318817 \\
EGMLY(-4) & -0.338195 & 0.18395 & -1.838519 \\
LOGFDIMLY & -23.54173 & 5.305878 & $-4.436916^{*}$ \\
LOGFDIMLY(-1) & 12.13089 & 6.797632 & 1.784576 \\
LOGFDIMLY(-2) & -5.091556 & 8.736273 & -0.582806 \\
LOGFDIMLY(-3) & -17.97491 & 9.549091 & -1.882369 \\
LOGFDIMLY(-4) & 14.07569 & 7.507563 & 1.874868 \\
LOGLFMLY & 10.15103 & 2.679683 & $3.788146 * *$ \\
LOGLFMLY(-1) & -8.56981 & 3.238977 & $-2.645838^{* *}$ \\
LOGLFMLY(-2) & -1.266837 & 3.172963 & -0.39926 \\
LOGLFMLY(-3) & -7.404035 & 3.953671 & -1.872699 \\
LOGEDMLY & 63.71001 & 16.41523 & $3.881152^{*}$ \\
LOGEDMLY(-1) & -73.83877 & 20.55924 & $-3.591513^{* *}$ \\
LOGEDMLY(-2) & 68.2752 & 22.177 & $3.078649^{* *}$ \\
LOGEDMLY(-3) & -51.1308 & 15.40067 & $-3.320037^{* *}$ \\
R-squared & 0.849737 & & \\
Adjusted & 0.667274 & & \\
R-squared & & & \\
F-statistic & 4.657047 & & \\
Prob(F-statistic) & 0.002871 & & \\
\hline & & & \\
\hline
\end{tabular}

Source: Secondary Data (processed)

Note: $\quad$ a. Dependent variable $=$ EGMLY

b. $* \alpha=1 \% ; * * \alpha=5 \%$; *** $\alpha=10 \%$

to achieve targeted economic growth. Furthermore, labour force has a positive and significant effect on economic growth while labour force $(-1)$ has negative and significant effect. Therefore, the Malaysian government needs to encourage the improvement of labour force (in terms of skill and productivity) to achieve domestic economic growth.

External debt used by Malaysian government and industry has a positive and significant impact on domestic economic growth. In addition, external debt (-2) also has a positive and significant effect, indicating that external debt is used carefully and properly to stimulate economic growth. However, external debt $(-1)$ and external debt $(-3)$ have a negative and significant impact on Malaysia's economic growth. Therefore, the Malaysian government needs to improve the governance and utilization of external debt.

The adjusted R-squared value of Malaysia's ARDL estimation is 0.667274 , which means that the variation of dependent variables is explained by the variation of independent variables by $66.7274 \%$. Furthermore, the Malaysia's ARDL estimation is categorized as a good model. The Malaysian ARDL estimation F-statistic value is 4.657074 , meaning that all independent variables simultaneously affect the dependent variables.

Table 9 confirms that in the long-run FDI and labour force effect on economic growth in Malaysia. Meanwhile, the external debt does not impact on economic growth. This means that Malaysia's economy tends depends on foreign capital inflow. Furthermore, Malaysia has labour force who need to be improved in form of skill and productivity.

\section{ECM ESTIMATION RESULTS}

Table 10 shows the results of ECM estimation in Indonesia in which the $\mathrm{D}$ (change) of economic growth lag 1 and lag 2 have a positive and significant impact on economic growth in the short-run. This indicates that the economic growth achieved in the current period is determined by the achievement in the previous period. In addition, change values of FDI lag $1, \operatorname{lag} 4$, and lag 5 have a negative and significant effect on economic growth while the change value of FDI lag 3 has a positive effect in the short-run. This means that FDI contributes significantly to the achievement of economic growth in Indonesia.

In the short-run, change value of external debt has no effect on economic growth. This means that the amount of labour does not reflect the achieved economic growth rate. Thus, the Indonesian government needs to formulate an employment policy that can stimulate increased domestic economic growth. Meanwhile, change value of external debt lag 1 to lag 5 have a positive and significant effect on economic growth in the short-run. This shows that external debt by the

TABLE 9. Long-Run Coefficient of Malaysian ARDL Estimation

\begin{tabular}{lcccc}
\hline Variable & Coefficient & Std. Error & t-Statistic & Prob. \\
\hline LOGFDIMLY & -8.79079 & 2.358592 & $-3.727134^{*}$ & 0.0023 \\
LOGLFMLY & -3.054838 & 1.532499 & $-1.99337 * * *$ & 0.0661 \\
LOGEDMLY & 3.02295 & 1.876033 & 1.611352 & 0.1294 \\
C & 79.414545 & 15.158019 & $5.239111^{*}$ & 0.0001 \\
\hline
\end{tabular}

Source: Secondary Data (Processed)

Note: a. Dependent variable is EGMLY

b. * $\alpha=1 \% ; * * \alpha=5 \% ; * * * \alpha=10 \%$ 
TABLE 10. ECM Estimation of Indonesia

\begin{tabular}{lccc}
\hline Variables & Coefficient & Std. Error & t-Statistic \\
\hline D(EGIND(-1)) & 1.055854 & 0.107803 & $9.794302^{*}$ \\
D(EGIND(-2)) & 0.215221 & 0.095227 & $2.260089^{* * *}$ \\
D(LOGFDIIND) & -0.338195 & 1.80024 & -0.187861 \\
D(LOGFDIIND(-1)) & -12.130894 & 2.550697 & $-4.755914^{* *}$ \\
D(LOGFDIIND(-2)) & 5.091556 & 2.957718 & 1.721448 \\
D(LOGFDIIND(-3)) & 17.974911 & 2.919044 & $6.157807^{*}$ \\
D(LOGFDIIND(-4)) & -14.075691 & 2.696932 & $-5.219149^{*}$ \\
D(LOGFDIIND(-5)) & -10.151029 & 0.324419 & $-31.289911^{*}$ \\
D(LOGLFIND) & -8.56981 & 95.339029 & -0.089888 \\
D(LOGLFIND(-1)) & 7.404035 & 116.326728 & 0.063649 \\
D(LOGLFIND(-2)) & -63.710015 & 57.264964 & -1.112548 \\
D(LOGLFIND(-3)) & 73.83877 & 54.383431 & 1.357744 \\
D(LOGLFIND(-4)) & -68.275201 & 47.953211 & -1.423788 \\
D(LOGLFIND(-5)) & 51.130801 & 43.027929 & 1.188317 \\
D(LOGEDIND) & 184.304847 & 10.257023 & $17.968649^{*}$ \\
D(LOGEDIND(-1)) & 47.906054 & 9.416678 & $5.087362^{*}$ \\
D(LOGEDIND(-2)) & 47.906054 & 11.029381 & $4.343494 *$ \\
D(LOGEDIND(-3)) & 47.906054 & 11.223093 & $4.268525^{*}$ \\
D(LOGEDIND(-4)) & 47.906054 & 10.309279 & $4.646887 *$ \\
D(LOGEDIND(-5)) & 47.906054 & 9.233149 & $5.188485^{*}$ \\
CointEq(-1) & -1.9826 & 0.13869 & $-14.29521^{*}$ \\
\hline Sourc: Seconay Dat & & &
\end{tabular}

Source: Secondary Data (processed)

Note: a. Dependent variable $=$ EGIND

b. Cointeq = EGIND $-(-5.3409 *$ LOGFDIIND $-5.1574 *$ LOGLFIND $-52.0183 *$ LOGEDIND -24.1633$)$ $=\mathrm{ECT}(-1)$

c. * $\alpha=1 \%$; ** $\alpha=5 \% ; * * * \alpha=10 \%$

government and private sector can drive economic growth in Indonesia.

One of the variables for measuring ECM estimation is ЕCT $(-1)$. The value of ECT $(-1)$ is negative and significant reflected by CointEq $(-1)$. This means that the ARDL-ECM estimation is appropriate to prove the impact of FDI, external debt, and labour force on Indonesia's economic growth in the short-run.

Table 11 illustrates the results of ECM estimation in Malaysia. Variables D (change) of economic growth lag 1 and lag 2 have a positive and significant impact on domestic economic growth in the short-run. These results reveal that the economic growth achieved in Malaysia is closely related to the achievements of economic growth in the previous period. Thus, the Malaysian government needs to stimulate economic growth to achieve established growth targets.

In the short-run, change value of FDI in Malaysia has a negative and significant effect on economic growth, indicating that FDI tends to hamper economic growth. To that end, the Malaysian government needs to manage and direct FDI to boost domestic economic growth.

Change value in labour force have a positive and significant effect on economic growth. This means that the number of labour forces can be used to stimulate economic growth. Thus, the Malaysian government can stimulate labour force (with increased skill and productivity) to achieve domestic economic growth. In addition, change value in external debts (external debt and external debt lag 2) has a positive and significant effect on economic growth in the short-run, while change value of external debt lag 1 has a negative and significant effect. This shows that external debt can be utilized to achieve domestic economic growth, but the Malaysian government needs to direct its utilization properly.

The ECT (-1) value of Malaysia's ECM estimation is negative and significant reflected by CointEq $(-1)$. This means that ECM estimation is appropriate to prove the impact of FDI, external debt, and labour force on the Malaysian economic growth in the short-run.

\section{STABILITY TEST RESULTS}

Stability tests with CUSUM (Cumulative Sum of Recursive Residuals) and CUSUMSQ (Cumulative Sum of Squares) were conducted to analyze the stability of ARDL estimates in Indonesia and Malaysia. The results of this test can also 
TABLE 11. ECM Estimation of Malaysia

\begin{tabular}{lccc}
\hline Variables & Coefficient & Std. Error & t-Statistic \\
\hline D(EGMLY(-1)) & 1.394049 & 0.349939 & $3.983687^{*}$ \\
D(EGMLY(-2)) & 0.553416 & 0.215551 & $2.567446^{* *}$ \\
D(EGMLY(-3)) & 0.338195 & 0.18395 & 1.838519 \\
D(LOGFDIMLY) & -23.541735 & 5.305878 & $-4.436916^{*}$ \\
D(LOGFDIMLY(-1)) & 5.091556 & 8.736273 & 0.582806 \\
D(LOGFDIMLY(-2)) & 17.974911 & 9.549091 & 1.882369 \\
D(LOGFDIMLY(-3)) & -14.075691 & 7.507563 & -1.874868 \\
D(LOGLFMLY) & 10.151029 & 2.679683 & $3.788146^{*}$ \\
D(LOGLFMLY(-1)) & 1.266837 & 3.172963 & 0.39926 \\
D(LOGLFMLY(-2)) & 7.404035 & 3.953671 & 1.872699 \\
D(LOGEDMLY) & 63.710015 & 16.415235 & $3.881152^{*}$ \\
D(LOGEDMLY(-1)) & -68.275201 & 22.177 & $-3.078649^{*}$ \\
D(LOGEDMLY(-2)) & 51.130801 & 15.400674 & $3.320037^{*}$ \\
CointEq(-1) & -2.320795 & 0.410287 & $-5.656509^{*}$ \\
\hline
\end{tabular}

Source: Secondary Data (processed)

Note: $\quad$ a. Dependent variable $=$ EGMLY

b. Cointeq $=$ EGMLY $-(-8.7908 *$ LOGFDIMLY $-3.0548 *$ LOGLFMLY + 3.0229*LOGEDMLY + 79.4145) $=$ ECT $(-1)$

c. $* \alpha=1 \%$;** $\alpha=5 \%$; *** $\alpha=10 \%$
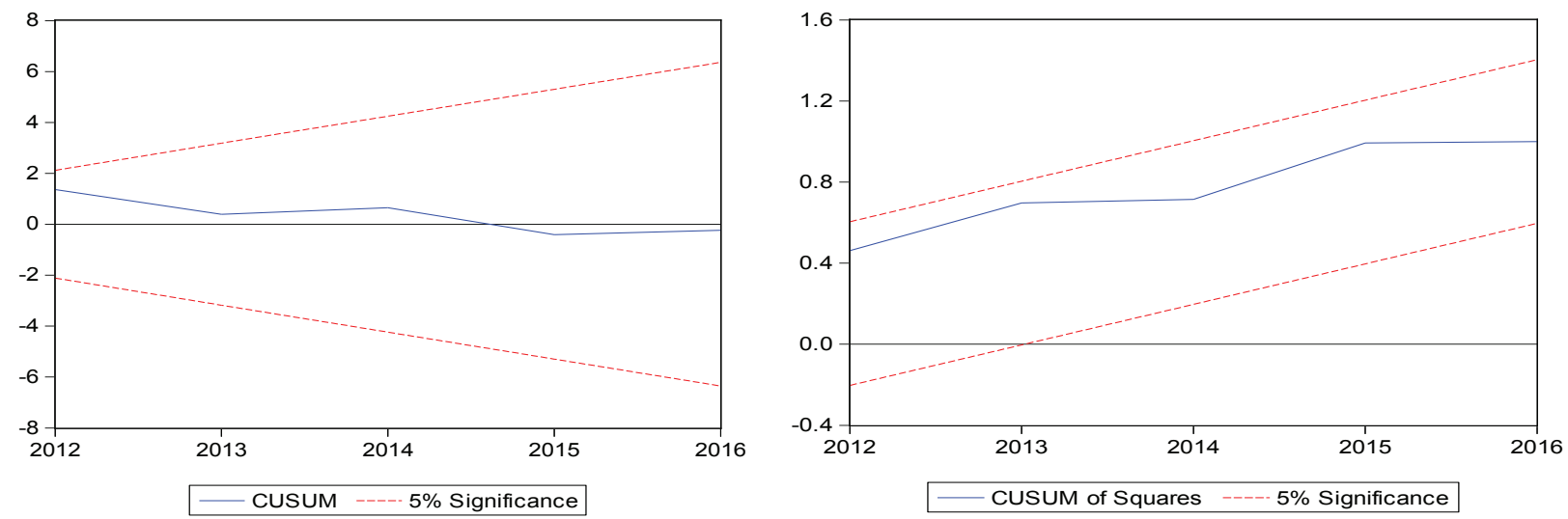

FIGURE 2. CUSUM and CUSUMSQ of ARDL Estimation in Indonesia Source: Secondary Data (Processed)
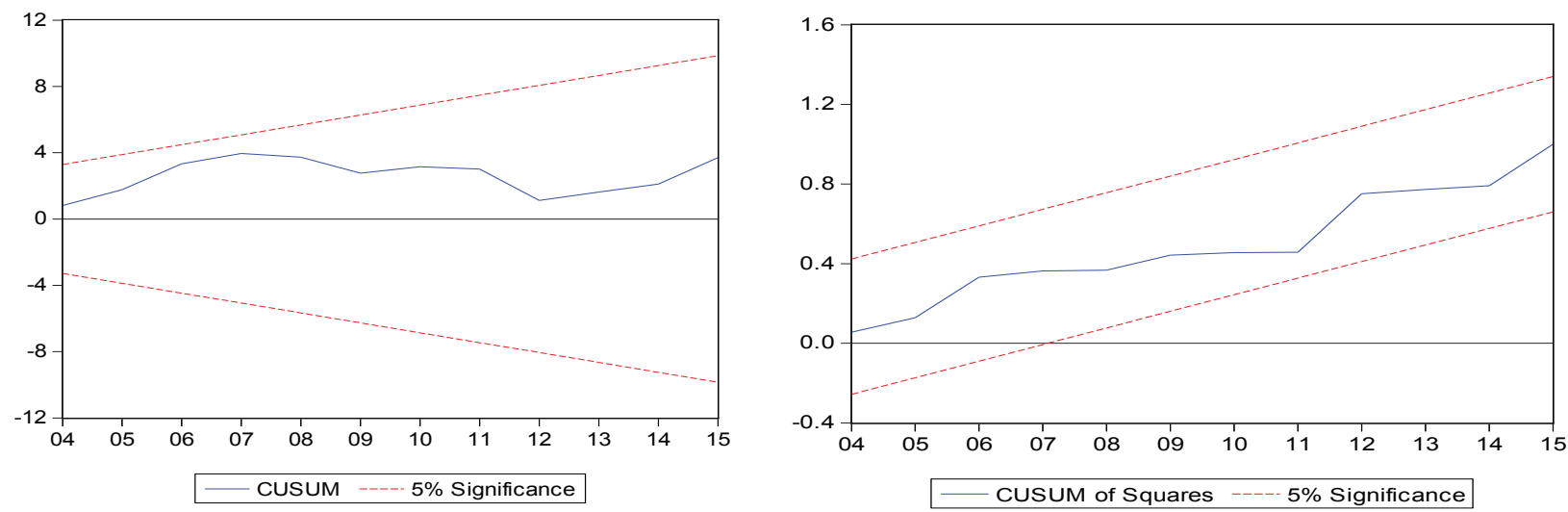

FIGURE 3. CUSUM and CUSUMSQ of ARDL Estimation in Malaysia Source: Secondary Data (Processed) 
be used to determine the robustness of ARDL estimates in Indonesia and Malaysia.

As shown in Figures 2 and 3, the CUSUM and CUSUMSQ results of ARDL Indonesia and Malaysia are stable. Thus, ARDL estimation models for both countries seem to be appropriate.

\section{CONCLUSION AND IMPLICATION}

The result of ARDL estimation has shown the existing long-run relationship between FDI, labour force, and external debt and economic growth for both countries, whereas their short-run relationship has been identified by the ARDL-ECM estimation results. In general, both estimation results indicate the impact of FDI, labour force, and external debt on economic growth in both countries. Meanwhile, the CUSUM and CUSUMSQ results confirm that ARDL estimation models for both Indonesia and Malaysia are stable.

The long-run relationship between FDI, labour force, and external debt with economic growth in Indonesia and Malaysia serves as a reference for the governments of both countries to manage, promote, and improve these variables in the future. This means that macroeconomic policies in both countries need to be directed to stimulate FDI and external debt to achieve economic growth targets. In addition, labour force policy should not only be oriented towards increasing labour force quantity in the labour market, but also on their quality that includes skill and productivity.

The result of short-run relationship between FDI, labour force, and external debt on economic growth in Indonesia and Malaysia can be a stimulus for domestic economic policy. This will encourage the government and the private sector to synergize their policy formulation and implementation in achieving their economic growth target in the short-run. Industries play an important role in managing FDI and external debt carefully and appropriately to promote increased productivity and business expansion. In addition, private sector can also prioritize the absorption of skilled and productive workers.

\section{REFERENCES}

Aw, Y. T. \& Tang, C. T. 2009. The Determinants of Inward Foreign Direct Investment: The case of Malaysia. Discussion Paper 22/09. Monash University.

Aljebrin, M. A. 2012. Labour Demand and Economic Growth in Saudi Arabia. American Journal of Business and Management 1 (4): 271-277.

Alimi, R. S. 2014. ARDL Bounds Testing Approach to Cointegration: A Re-Examination of Augmented Fisher Hypothesis in an Open Economy. Asian Journal of Economic Modelling 2(2): 103-114.

Allen, E. R. 2016. Analysis of Trends and Challenges in the Indonesian Labour Market. ADB Paper No. 16.
Aurangzeb \& Haq, A. U. 2012. Impact of Investment Activities on Economic Growth of Pakistan. Business and Management Review 2 (1): 92-100.

Bakar, N. A. A. \& Hassan, S. 2008. Empirical Evaluation on External Debt of Malaysia. International Business and Economics Research Journal 7 (2): 95-108.

Buffie, E. E., et.al. 2012. Public Investment, Growth, and Debt Sustainability: Putting Together the Pieces. IMF Working Paper WP/12/144, June.

Daud, S. T. 2016. The Real Effect of Government Debt: Evidence from the Malaysian Economy. Journal of Economic Cooperation and Development 37 (3): 57-86.

Drabble, J. H. 2000. An Economic History of Malaysia, c. 18001990: The Transition to Modern Economic Growth. London: Macmillan Press and New York: St. Martin's Press.

Duasa, J. 2007. Malaysian Foreign Direct Investment and Growth: Does Stability Matter? Journal of Economic Cooperation 28 (2): 83-98.

Emeka, E. J. \& Mojekwu, J. N. 2011. The Impact of External Debt on Macro-Economic Performance. International Journal of Business and Management Tomorrow 1 (2). ISSN 2249-9962 November in www.ijbmt.com.

Feriyanto, N. \& Sriyana, J. 2016. Labour Absorption Under Minimum Wage Policy in Indonesia. Regional Science Inquiry VIII (1): 11-21.

Giap, T. K. \& Amri, M. 2016. Economic Growth in East Java, Indonesia: A Geweke Causality Analysis. International Journal of Business and Social Science 7 (7): 82-93.

Gopalan, S., Hattari, R., \& Rajan, R. S. 2016. Understanding foreign direct investment in Indonesia. Journal of International Trade Law and Policy 15 (1): 28-50.

Greiner, A. \& Fincke, B. 2015. Public Debt Sustainability and Economic Growth: Theory and Empirics. Switzerland: Springer International Publishing.

Hafild, E., Furqon, D., Hidayati, N. \& Sangkoyo, H. 2000. Addicting to Loan: The World Bank Foot Prints in Indonesia. WALHI Briefing Paper.

Hakim, A. \& Giovani, G. 2012. Perbandingan Perekonomian dari Masa Soekarno Hingga Susilo Bambang Yudhoyono (1945-2009) (The Comparison of Economy from Soekarno until Susilo Bambang Yudhoyono (1945-2009). Ekonomika-Bisnis 03 (2): 161-180.

Haseeb, M., et al. 2014. Exports, Foreign Direct Investment and Economic Growth: Empirical Evidence From Malaysia (1971-2013). American Journal of Applied Sciences 11 (6): 1010-1015.

Hassan, M. K. H. \& Masron, T. A. 2011. Inward FDI from ASEAN and Its Implication on Malaysian Manufacturing Sector. Jurnal Ekonomi Malaysia 45: 33-39.

Helbling, T., M., Ashoka \& Sahay, R. 2004. Debt Accumulation in the CIS-7 Countries: Bad Luck, Bad Policies, or Bad Advice? IMF Working Paper WP/04/93.

Hooi, L. H. \& Wah, T. B. 2010. Linkages Between Foreign Direct Investment, Domestic Investment And Economic Growth In Malaysia. Prosiding PERKEM V 2: 48-57.

Hsu, Y. H. 2017. Population Aging, Labour Force Participation, and Economic Growth. Journal of Business \& Economic Policy 4 (1): 119-129.

ILO, OECD \& World Bank Group. 2015. The Contribution of Labour Mobility to Economic Growth. G20 Labour and Employment Ministers' Meeting. Turkey. 
Nkoro, E. \& Uko, A. K. 2016. The Johansen-Juselius Multivariate Cointegration Technique: Application and Interpretation. Advances in Social Sciences Research Journal 3 (4): 248-267.

Kentjana, N. R. 2017. Opportunities for Foreign Direct Investment in Indonesia. Thailand Overseas Investment Forum.

Loganathan, N., Sukemi, M. N. \& Sanusi, N. A. 2010. External Debt and Macroeconomics Performance In Malaysia: Sustainable or Not? Global Economy and Finance Journal 3 (2): 122-132.

Maddala, G. S. \& Kim, I. M. 2004. Unit Roots, Cointegration, and Structural Change. UK: Cambridge University Press.

Mahadika, I. N., Kalayci, S. \& Altun, N. 2017. Relationship between GDP, Foreign Direct Investment and Export Volume: Evidence from Indonesia. International Journal of Trade, Economics and Finance 8 (1): 51-54.

Mengus, E. 2014. Foreign Debt and Ricardian Equivalence. Job Market Paper 2, January.

Mohamed, M. R. et al. 2014. Impact of Foreign Aid and Foreign Direct Investment on Economic Growth: Evidence from Sub-Saharan African Countries Jurnal Ekonomi Malaysia 48(1): 63-73.

Mun, H. W., Lin, T. K. \& Man, Y. K. 2008. FDI and Economic Growth Relationship: An Empirical Study on Malaysia. International Business Research 1 (2): 11-18.

Munir, Q., Nasir, W. A., \& Ching, K. S. 2016. Determining the Optimal Level of External Debt and Debt-Growth Relation: A Case Study of Malaysia. Proceedings of the Annual Vietnam Academic Research Conference on Global Business, Economics, Finance \& Social Sciences. Vietnam.

Nersisyan, Y. \& Wray, L. R. 2010. Does Excessive Sovereign Debt Really Hurt Growth? A Critique of This Time Is Different, by Reinhart and Rogoff. Working Paper No. 603 June. Levy Economics Institute.

Nordin, N. Na., Zainudin, N. \& Hameed, L. M. 2014. Labour Market Flexibility, Foreign Direct Investment and Economic Growth in Malaysia. E-proceedings of the Conference on Management and Muamalah (CoMM) 2627 May pp. 173-180.

Pattillo, C., P., Hélène \& Ricci, L. 2004. What Are the Channels Through Which External Debt Affects Growth? IMF Working Paper WP/04/15.

Paudel, R. C. \& Perera, N. 2009. Foreign Debt, Trade Openness, Labour Force and Economic Growth: Evidence from Sri Lanka. The ICFAI Journal of Applied Economics 8 (1): 57-64.

Pesaran, M. H. \& Shin, Y. 1995. An Autoregressive Distributed Lag Modelling Approach to Cointegration Analysis. The Symposium at the Centennial of Ragnar Frisch. The Norwegian Academy of Science and Letters. Oslo.

Pesaran, M.H., Shin, Y., \& Smith, R.J. 2001. Bounds testing approaches to the analysis of level relationships. Journal of Applied Econometrics, 16 (3): 289-326.

Phetsavong, K. \& Ichihashi, M. 2012. The Impact of Public and Private Investment on Economic Growth: Evidence from Developing Asian Countries. IDEC Discussion paper Hiroshima University.

Poirson, H. 2000. The Impact of Intersectoral Labour Reallocation on Economic Growth. IMF Working Paper $\mathrm{WP} / 00 / 104$.
Rafik, R. A. M 2015. Determinants of External Debt: The Case of Malaysia. Cyprus: Eastern Mediterranean University.

Rininta, N. 2013. The Causality of FDI Inflow and Economic Growth in Indonesia. MPRA Paper No. 46572 April.

Romer, D. 2012. Advanced Macroeconomics. Fourth Edition. USA: McGraw-Hill.

Sailiwa, W. S. 2013. Potensi Usaha Bersama Ekonomi MalaysiaIndonesia Dalam Meningkatkan Daya Saing Regional dan Global (Economic Cooperation of Malaysia-Indonesia for Increasing Regional and Global Competitiveness). International Seminar of Malaysia-Indonesia Friendship. Kualla Lumpur.

Setterfield, M. (ed.). 2010. Handbook of Alternative Theories of Economic Growth. UK: Edward Elgar Publishing Limited.

Sieng, L. W. \& Yussof, I. 2014. Human Capital Accumulation and Economic Growth in Malaysia - Investigating the Long Run Nexus. Jurnal Ekonomi Malaysia 48 (1): 155-165.

Sjöholm, F. 2016. Foreign Direct Investment and Value Added in Indonesia. IFN Working Paper No. 1141.

Solomon, C., Islam, A. \& Bakar, R. 2015. Attracting Foreign Direct Investment: The case of Malaysia. International Business Management 9 (4): 349-357.

Suhendra, I. \& Anwar, C. J. 2014. Determinants of Private Investment and The Effects on Economic Growth in Indonesia. GSTF International Journal on Business Review (GBR) 3 (3): 129-133.

Tarmidi, D., Utami, E. M. \& Salahudin. 2014. Analysis of Direct Foreign Investment on Indonesia's Export and Economic Growth. $12^{\text {th }}$ EBES Conference Proceedings. January. Singapore.

Ullah, I., Shah, M. \& Khan, F. U. 2014. Domestic Investment, Foreign Direct Investment, and Economic Growth Nexus: A Case of Pakistan. Hindawi Publishing Corporation.

Umaru, A., Hamidu, A. A. \& Musa, S. 2013. External Debt and Domestic Debt Impact on the Growth of the Nigerian Economy. International Journal Educational Research 20131 (2).

Wehinger, G. 2011. Fostering Long-term Investment and Economic Growth: Summary of a High-Level OECD Financial Roundtable. OECD Journal: Financial Market Trends (1): 18-21.

Wijeweera, A., Dollery, B. \& Parthberiya, P. 2005. Economic Growth and External Debt Servicing: A Cointegration Analysis of Sri Lanka, 1952 - 2002. Working Paper Series in Economics No. 2005-8 School of Economics University of New England.

Wong, K. N. 2013. Outward FDI and Economic Growth in Malaysia: An Empirical Study. International Journal of Business and Society 14 (1): 163-172.

Wickens, M. 2008. Macroeconomic Theory: A Dynamic General Equilibrium Approach. New Jersey: Princeton University Press.

Wye, C. K. \& Ismail, R. 2012. Labour Market Structure in Malaysia: Pre- and Post- Market Gender Comparison. International Journal of Academic Research in Business and Social Science 2 (10): 259-283.

Yusof, S. A. 2010. Globalization and the Malaysian Labour Market: An Empirical Investigation. Journal of Economic Cooperation and Development 31 (1): 17-40. 
Malik Cahyadin*

Universitas Sebelas Maret

J1. Ir. Sutami No.36 A

Pucangsawit Kec. Jebres Kota Surakarta

Jawa Tengah 57126

INDONESIA

E-mail: malikcahyadin@gmail.com
Tamat Sarmidi

Fakulti Ekonomi dan Pengurusan

Universiti Kebangsaan Malaysia

43600 UKM Bangi Selangor

MALAYSIA

E-mail: tamat@ukm.edu.my

*Corresponding author 


\section{APPENDIX}

TABLE A. Description of Research Variables

\begin{tabular}{|c|c|c|}
\hline Variables & Description & Measurement \\
\hline Economic Growth & $\begin{array}{l}\text { Annual economic growth of Indonesia (IND) and Malaysia (MLY) } \\
\text { from the years of 1980-2016. }\end{array}$ & $\begin{array}{l}\text { Data are in \%. It is symbolized by EGIND and } \\
\text { EGMLY. }\end{array}$ \\
\hline FDI & $\begin{array}{l}\text { Foreign direct investment are the net inflows of investment to } \\
\text { acquire a lasting management interest ( } 10 \text { percent or more of } \\
\text { voting stock) in an enterprise operating in an economy other than } \\
\text { that of the investor. It is the sum of equity capital, reinvestment of } \\
\text { earnings, other long-term capital, and short-term capital as shown } \\
\text { in the balance of payments. This series shows total net FDI. In } \\
\text { BPM6, financial account balances are calculated as the change in } \\
\text { assets minus the change in liabilities. Net FDI outflows are assets } \\
\text { and net FDI inflows are liabilities. }\end{array}$ & $\begin{array}{l}\text { Data are in current U.S. dollars. It was converted } \\
\text { into log. The symbols of variables are logFDIIND } \\
\text { and logFDIMLY. }\end{array}$ \\
\hline Labour Force & $\begin{array}{l}\text { Total labour force both in Indonesia (IND) and Malaysia (MLY) } \\
\text { from the years of 1980-2016. }\end{array}$ & $\begin{array}{l}\text { Data are in person. It was converted into log. } \\
\text { The symbols of variables are logLFIND and } \\
\text { logLFMLY. }\end{array}$ \\
\hline External Debt & $\begin{array}{l}\text { Total external debt is debt owed to nonresidents repayable in } \\
\text { foreign currency, goods, or services. Total external debt is the } \\
\text { sum of public, publicly guaranteed, and private nonguaranteed } \\
\text { long-term debt, use of IMF credit, and short-term debt. Short-term } \\
\text { debt includes all debt having an original maturity of one year or } \\
\text { less and interest in arrears on long-term debt. }\end{array}$ & $\begin{array}{l}\text { Data are in current U.S. dollars. It was converted } \\
\text { into log. The symbols of variables are logEDIND } \\
\text { and logEDMLY. }\end{array}$ \\
\hline
\end{tabular}

Source: The World Bank and Author Data Set 